\title{
Family Circumstances Forcing Children to Run Away from Home in Cameroon
}

\author{
Samuel Nambile Cumber ${ }^{1}$, Joyce Mahlako Tsoka-Gwegweni ${ }^{1, ~ *, ~}$ \\ Rosaline Yumumkah Kanjo-Cumber ${ }^{2}$ \\ ${ }^{1}$ Discipline of Public Health Medicine, Department of Nursing \& Public Health, College of Health Sciences, University of Kwazulu-Natal, \\ Durban, South Africa \\ ${ }^{2}$ Department of Political Science, University of Kwazulu-Natal, Durban, South Africa
}

\author{
Email address: \\ Tsokagwegweni@ukzn.ac.za (J. M. Tsoka-Gwegweni) \\ ${ }^{*}$ Corresponding author
}

\section{To cite this article:}

Samuel Nambile Cumber, Joyce Mahlako Tsoka-Gwegweni, Rosaline Yumumkah Kanjo-Cumber. Family Circumstances Forcing Children to Run Away from Home in Cameroon. Science Journal of Public Health. Vol. 5, No. 1, 2017, pp. 1-9. doi: 10.11648/j.sjph.20170501.11

Received: August 10, 2016; Accepted: September 1, 2016; Published: December 8, 2016

\begin{abstract}
Home background plays a very significant role in the lives of children. The love, respect and attention given to a child at home greatly influences his/her belonging to that home. Knowing the conditions of children at home is imperative if we wish to tackle the problems of street children in Cameroon. This study was to identify and assess the factors associated with the phenomenon of urban street adolescents in 3 cities in Cameroon by looking at the family conditions regarding children's decision to run away from home. This cross sectional study was carried out on a non-probability snow-ball sample of 399 street children aged 12 to 17 , with selection based on their availability and inclusion criteria. Data was collected through interpersonal administration of questionnaires then analysed by univariate and bivariate calculation of frequencies as well as cross tables and chi-square (at what level of significance?). After data collection and cleaning, data was captured in Microsoft Excel (2010) spreadsheet and imported into SPSS statistical package version 19 for windows (IBM Corp., Armonk, NY, USA, for analysis). The study results showed that $75.2 \%$ of the participants could not meet their needs while at home, due to the poor status of their parents/guardians as confirmed by $84.5 \%$ of them. It should also be noted that $74.7 \%$ of participants reported not able to have sufficient meals while at home. Additionally, $70 \%$ of participants lived with troublesome (use a different word) parents/guardians such as drunkard or those who are mentally unstable and consequently they had neither respect nor affection for them. The study concluded that the participants experienced unfavourable home circumstances which contributed to them leaving/running from home to dwell on the streets. The Cameroon government should therefore play a major role in assisting street children to ensure that their rights and basic needs are met.
\end{abstract}

Keywords: Family, Street Children, Run Away, Cameroon

\section{Introduction}

Poverty has been identified as one of the reasons why vulnerable children are forced to work and live on the streets in most urban cities around the world [1]. The situation is more complex in low and middle income countries [1]. Getting the exact number of street children has been impossible because of their mobile life style nevertheless; UNICEF estimates the number to hundreds of thousands around the world [1].

Some societies view these vulnerable children in difficult circumstances as vermin that must be discarded from the society, every one blaming the victims and almost never the perpetrators $[1,2]$.

Home background plays a very significant role in the lives of children which is seen as a complexity of social status, family economy, culture and personal factors affecting everyone in the family [3, 4]. For instance, parents with low income have to work long hours to get some income which leaves them with little time to pay full attention towards their 
children [5].

Children run away from homes in Cameroon because of many push and pull factors. Some children see their homes as being uncomfortable to live in due to some factors such as lack of love and concern reasons why they run into the streets as early as 9 years old $[3,4]$. Street children are mostly found in urban centres and about $75 \%$ of street children are school drop-outs while the remaining $25 \%$ of them have never been to school [6-8].

Generally in the Cameroon society, parents question and put their children under control meanwhile some others pay little or no attention towards their children which means giving a blind eye to whatever offense their children commit irrespective of its intensity thereby putting the children in a confused state $[3,8]$. In such a family setting, children are free to do whatever they want such as being in the company of bad friends, gangs, sleeping out at night without being questioned by their parents when they return [3-5]. On the other hand majority of parents in Cameroon have been extremely harsh when disciplining their children such that even for simple offences which the parents could have called for the child's attention or given a simple advice, they turn to give harsh punishments such as beating, starvation, and inflicting physical pain [3, 4, 6-8].

Also because of the economic crises and poverty in Cameroon, a large number of families have been affected with deadly disease such as HIV/AIDS which took the lives of thousands of adults thereby leaving behind hundreds of orphans and street children with no one to provide basic needs for them [5, 9]. Also, many push factors such as alcohol and drug abuse, divorce, rape and family violence has led to dysfunctional families thereby causing some children to run away from home into the streets of urban cities $[10,11]$.

Parents' behaviours can either encourage or discourage a child from running to the streets. In Cameroon, parents behaviours and the upbringing methods used in raising their children differ from parent to parent [3].

Some studies have shown that, parents value different things such as neatness, obedience, cleanliness, respect and some insisting that their children must grow up with traditional standard of behaviour in the society [3, 4]. In another word children in this setting have no say but just have to do as they are being told to do [3, 4]. Also within same setting, the parent expects that when a child commits an offense the child should be ready to accept the immediate consequences/punishment and this makes parents to enforce discipline with physical punishment $[3,4,12]$. Some other parents are more concerned with their children's intention and the motive behind which the crime was committed [3, 4].

Despite the different methods, most parents believe that only corporal punishment helps to straighten up a child in preparation for his or her future [3, 4, 12]. These parents even go as far as punishing children when they perform poorly in school $[3,4]$. Also, some parents punish their children for calling them all sorts of negative names or embarrassing them in schools, public and in the presence of their friends
$[3,4]$.

This study focused mainly on home upbringing methods, aiming to understand family circumstances which forces children to run away from their homes to the streets in Cameroon. Specifically this study refers to the ways in which children are being brought-up in homesand parent's behaviours which either encourages or discourages their children to run to the streets in the cities of Bamenda, Douala and Yaoundé.

\section{Materials and Methods}

\subsection{Study Site}

The study was conducted in the Republic of Cameroon which is a sub-Saharan African country. Three urban cities in Cameroon namely Bamenda, Douala and Yaoundé were selected and used in this study.

\subsection{Study Design}

This study was part of a comprehensive cross-sectional survey. Conducted between the $1^{\text {st }}$ of January 2015 to the $30^{\text {th }}$ of March 2015, to investigate family circumstances that contributed to children leaving their homes to dwell on the streets.

\subsection{Study Population}

Children living on the streets in Cameroon are often referred to as "street children" and in this study they will be referred as such. The study population for this study was street children in Cameroon. The study however focused on the street children in the urban cities of Bamenda, Douala and Yaoundé. Bamenda is the most populated Englishspeaking city in Cameroon. Douala is the economic capital of Cameroon which is a French-speaking urban city and the most populated city in Cameroon while Yaoundé, is a French-speaking urban city and is the capital of the Republic of Cameroon. These three cities were selected because they are known to accommodate large numbers of street children.

\subsection{Sampling}

With the help of peers, a non-probability technique of snowball sampling was used. This is a process whereby each recruited participant led the researcher to other participants. This method was considered most suitable in this study because of the mobile lifestyle of street children (hard to reach population), limited data, absent of national reports or census on street children in Cameroon.

\subsection{Data Collection Instruments}

The main instrument used to collect data for this study was a self designed questionnaire. The questionnaire was designed by the authors. The questionnaires were written in English and French languages, and were also translated into pidgin English which is a language frequently use in Cameroon and amongst street children especially in the city 
of Bamenda.

\subsection{Data Collection}

Recruitment and enrolment took place at the usual gathering points for street children which were identified as bus stations, train stations, market and city centres and in front of movie houses. Data was collected using intervieweradministering questionnaires at a quite location provided by the catholic church. The street children self reported their ages and the study did not use any additional method to identify or verify their responses. No identity cards or birth certificates were required from the participants, thus the study results relied only on what the children reported orally. Before the data collection process started, a two day training was given to the six research assistants to enable that they all understood the questionnaire in a similar way. The local Catholic Church provided a quite facility which was used to administer the self designed questionnaires to the participants.

After the interview no monetary compensation was provided but participants were given food and transported back to their chosen locations.

\subsection{Sample Size}

A total of 405 street children aged 12 to 17 were recruited for this study. This sampling strategy was suitable because street children are highly mobile. Six participants were excluded due to incomplete information on the questionnaire and this resulted in 399 participants who finally took part in this study.

A $50 \%$ prevalence value of street children was used during the sample size calculation of this study. This was considered as the best option at the time of the study because there were no published prevalence data on street children in Cameroon.

This study is based on the following formula:

$$
n=\frac{Z^{2} * P(1-P) D E F F}{d^{2}}
$$

Where,

- $\mathrm{n}$ is the target sample size

- $\mathrm{Z}$ is the $\mathrm{Z}$ statistics for a level of confidence (here $Z=1.96$ i.e. for a $95 \%$ confidence interval)

- $\mathrm{P}$ is the estimated proportion of street children. Because there is no documented prevalence of street children in the setting, the calculation assumed a $50 \%(0.5)$ prevalence $(\mathrm{P})$ since this will produce the largest number of sample size required.

- $\mathrm{d}$ is the absolute precision i.e. the width of the confidence interval to be $5 \%(0.05)$

- DEFF (Design effect): Used a clustered-randomized study where the different cities are the primary sampling units. The same number of participants was used in the different cities of the study, giving a design effect to be 1 [6].

Therefore, our

$$
n=\frac{1.96^{2}(0.5)(1-0.5)(1)}{0.05^{2}}=385
$$

Because of the study population in this study, it was assumed that $5 \%$ of the questionnaire would be wrongly filled in or uncompleted reasons why the study proposed for additional questionnaires. With this in mind 20 more participants were added which gave a total of 405 targeted participants $(0.05 * 385=20$, given $385+20=405$ participants).

\subsection{Data Analysis}

After collection and cleaning of the data, the data was captured in Microsoft Excel (2010) spreadsheet and imported into SPSS statistical package version 19 for windows (IBM Corp., Armonk, NY, USA) for analysis. The data was analysed using analysis which included univariate and bivariate calculations of frequency distributions and cross tabulations used to summarize the data. Chi-square test of association was also used to assess whether there was any association between regions and other categorical variables with a $5 \%$ significance level.

\subsection{Ethical Consideration}

To protect the identity of the participants, no names were written on the questionnaires but, unique numbers were assigned to each participant for the purpose of the research only. Only the primary researcher had access to the collected data. Though the participants were all minors, obtaining the permission of their parents/guardians in the case of street children was not possible. Only written informed consent form was obtained. The participants provided written consent in addition to the ethical approvals granted by the Biomedical Research Ethics Committee (BREC), University of KwaZulu-Natal, Durban, South Africa and the Cameroon Bioethics Initiative (CAMBIN).

After administering of the questionnaires food was given to the street children who participated as well as other street children who happened to be around with no monetary incentive provided.

\subsection{Inclusion Criteria}

The study was mainly on street children below the age of 18 who have taken the street to be their source of livelihood and habitual abode without any proper adult supervision. The study included only children who have been living on the streets of Bamenda, Douala and Yaoundé urban cities for a duration of one month or more.

\section{Results}

\subsection{Demographic}

This study was conducted on 399 street children out of which $80.2 \%$ were male and $19.8 \%$ female. The respondents' religious pattern showed that $83 \%$ of them were Christians 
while Muslims and Traditional/no religion comprised of $7 \%$ of the participants. $80 \%$ of the participants had no contact with their family members. Only $10 \%$ are having a monthly contact with family members especially participants in Yaoundé and Douala. More than half of the participants begged to make ends meet while a good number of them were engaged in other activities like selling in bars, shining shoes, washing cars and worst of all engaging into mini theft as shown in table 1 .

Table 1. Demographic characteristics.

\begin{tabular}{|c|c|c|c|c|c|c|c|c|}
\hline \multirow{2}{*}{ Characteristics } & \multirow{2}{*}{$\begin{array}{l}\text { Total } \\
\mathbf{N}^{\mathbf{0}}(\%)\end{array}$} & \multicolumn{2}{|c|}{ Bamenda $(n=125)$} & \multicolumn{2}{|c|}{ Douala $(n=137)$} & \multicolumn{2}{|c|}{ Yaoundé (137) } & \multirow[t]{2}{*}{$P$-value } \\
\hline & & $\mathbf{N}^{\mathbf{0}}$ & $\%$ & $\mathbf{N}^{\mathbf{0}}$ & $\%$ & $\mathbf{N}^{0}$ & $\%$ & \\
\hline \multicolumn{9}{|l|}{ Sex } \\
\hline Male & $320(80.2)$ & 108 & 86.4 & 101 & 73.7 & 111 & 81 & 0.035 \\
\hline Female & $79(19.8)$ & 17 & 13.6 & 36 & 26.3 & 26 & 19 & \\
\hline \multicolumn{9}{|l|}{ Age } \\
\hline $12-14$ & $89(22.3)$ & 29 & 23.2 & 31 & 22.6 & 29 & 21.2 & 0.919 \\
\hline $15-17$ & $310(77.7)$ & 96 & 76.8 & 106 & 77.4 & 108 & 78.8 & \\
\hline \multicolumn{9}{|l|}{ Religion } \\
\hline Christian & $331(83)$ & 99 & 79.2 & 121 & 88.3 & 111 & 81 & 0.016 \\
\hline Islam & $36(9)$ & 9 & 7.2 & 13 & 9.5 & 14 & 10.2 & \\
\hline Tradition/none & $32(8)$ & 17 & 13.6 & 3 & 2.2 & 12 & 8.8 & \\
\hline \multicolumn{9}{|l|}{ Frequency of family contact } \\
\hline No contact & $352(88.2)$ & 103 & 82.4 & 123 & 89.8 & 126 & 92 & 0.009 \\
\hline monthly & $42(10.5)$ & 17 & 13.6 & 14 & 10.2 & 11 & 8 & \\
\hline Others & $5(1.3)$ & 5 & 4 & 0 & 0.0 & 0 & 0.0 & \\
\hline \multicolumn{9}{|l|}{ Main economic activity } \\
\hline Begging/support from friends & $235(58.9)$ & 73 & 58.4 & 83 & 60.6 & 79 & 57.7 & 0.374 \\
\hline Guarding/washing cars & $41(10.3)$ & 13 & 10.4 & 15 & 11 & 13 & 9.5 & \\
\hline Shoe shinning & $23(5.8)$ & 7 & 5.6 & 7 & 5.1 & 9 & 6.6 & \\
\hline Work in small restaurants/bar/clubs & $74(18.6)$ & 18 & 14.4 & 27 & 19.7 & 29 & 21.2 & \\
\hline Stealing (pick pocket) & $26(6.5)$ & 14 & 11.2 & 5 & 3.7 & 7 & 5.1 & \\
\hline
\end{tabular}

\subsection{Family Profiles of Respondents}

The data bellow on table 2 is on the family background of respondents from all three urban cities (Bamenda, Douala and Yaoundé). $72.4 \%$ of respondents said they used to live with their parents, $19.3 \%$ with relatives and $8.3 \%$ lived with their guardians.

Regarding parents marital status, $24.6 \%$ of the participants reported monogamy as their parents marital status, $50.9 \%$ said polygamy and $24.5 \%$ said their parents were never married. Additionally, $26.6 \%$ of fathers had no education, $47.6 \%$ had primary education, $22.6 \%$ had secondary education and only $3.3 \%$ had up to university education. In the case of occupation, $10.5 \%$ of respondents fathers were unemployed, $68.9 \%$ were farm/plantation workers, $13.5 \%$ were self-employed and only $7 \%$ were civil servants. The same trend was noticed in relation to education and employment in respondents' mothers.

It was also reported that $73.9 \%$ of the respondents had a family member/guardian who abused drugs or alcohol in all three cities, with Yaoundé, Douala and Bamenda reporting $79.6 \%, 73 \%$ and $68.8 \%$ respectively. Lastly, $26.5 \%$ of the respondents had family member whom have been in prison or still in prison.

Table 2. Family profile of respondents by city of residence.

\begin{tabular}{|c|c|c|c|c|c|c|c|c|}
\hline \multirow{2}{*}{ Characteristics } & \multirow{2}{*}{$\begin{array}{l}\text { Total }(n=399) \\
N^{0}(\%)\end{array}$} & \multicolumn{2}{|c|}{ Bamenda $(n=125)$} & \multicolumn{2}{|c|}{ Douala $(n=137)$} & \multicolumn{2}{|c|}{ Yaoundé (137) } & \multirow[t]{2}{*}{$P$-value } \\
\hline & & $\mathbf{N}^{0}$ & $\%$ & $\mathbf{N}^{\mathbf{0}}$ & $\%$ & $\mathbf{N}^{\mathbf{0}}$ & $\%$ & \\
\hline \multicolumn{9}{|l|}{ Used to live with } \\
\hline Parents & $289(72.4)$ & 89 & 71.2 & 96 & 70 & 104 & 75.9 & 0.420 \\
\hline Relatives & $77(19.3)$ & 25 & 20 & 32 & 23.4 & 20 & 14.6 & \\
\hline Guardian & $33(8.3)$ & 11 & 8.8 & 9 & 6.6 & 13 & 9.5 & \\
\hline \multicolumn{9}{|l|}{ Parent marital status } \\
\hline Monogamy & $98(24.6)$ & 21 & 16.8 & 47 & 34.3 & 30 & 21.9 & 0.000 \\
\hline Polygamy & $203(50.9)$ & 56 & 44.8 & 67 & 48.9 & 80 & 58.4 & \\
\hline Never married & $98(24.6)$ & 48 & 38.4 & 23 & 16.8 & 27 & 19.7 & \\
\hline \multicolumn{9}{|c|}{ Male parent level of education } \\
\hline No education & $106(26.6)$ & 23 & 18.4 & 47 & 34.3 & 36 & 26.3 & 0.000 \\
\hline Primary & $190(47.6)$ & 55 & 44 & 60 & 43.8 & 75 & 54.7 & \\
\hline Secondary & $90(22.6)$ & 45 & 36 & 26 & 19 & 19 & 13.8 & \\
\hline University & $13(3.3)$ & 2 & 1.6 & 4 & 2.9 & 7 & 5.1 & \\
\hline
\end{tabular}




\begin{tabular}{|c|c|c|c|c|c|c|c|c|}
\hline \multirow{2}{*}{ Characteristics } & \multirow{2}{*}{$\begin{array}{l}\text { Total }(\mathrm{n}=399) \\
\mathbf{N}^{\circ}(\%) \\
\end{array}$} & \multicolumn{2}{|c|}{ Bamenda $(\mathrm{n}=125)$} & \multicolumn{2}{|c|}{ Douala $(n=137)$} & \multicolumn{2}{|c|}{ Yaoundé (137) } & \multirow[t]{2}{*}{$P$-value } \\
\hline & & $\mathbf{N}^{0}$ & $\%$ & $\mathbf{N}^{0}$ & $\%$ & $\mathbf{N}^{\mathbf{0}}$ & $\%$ & \\
\hline Unemployed & $42(10.5)$ & 8 & 6.4 & 19 & 13.9 & 15 & 10.9 & 0.000 \\
\hline Farmer/plantation worker & $275(68.9)$ & 96 & 76.8 & 94 & 68.6 & 85 & 62 & \\
\hline Self employed & $54(13)$ & 21 & 16.8 & 10 & 7.3 & 23 & 16.8 & \\
\hline Government civil servant & $28(7)$ & 0 & 0.0 & 14 & 10.2 & 14 & 10.2 & \\
\hline \multicolumn{9}{|c|}{ Female parent level of education } \\
\hline No education & $196(49.1)$ & 46 & 36.8 & 72 & 52.6 & 78 & 56.9 & 0.002 \\
\hline Primary & $186(46.6)$ & 75 & 60 & 61 & 44.5 & 50 & 36.5 & \\
\hline Secondary & $17(4.3)$ & 4 & 3.2 & 4 & 2.9 & 9 & 6.6 & \\
\hline \multicolumn{9}{|l|}{ Female parent occupation } \\
\hline House wife & $119(29.8)$ & 40 & 32 & 46 & 33.6 & 33 & 24.1 & 0.000 \\
\hline Farmer/plantation worker & $196(49.1)$ & 74 & 59.2 & 61 & 44.5 & 61 & 44.5 & \\
\hline Self employed & $72(18.1)$ & 11 & 8.8 & 30 & 21.9 & 31 & 22.6 & \\
\hline Government civil servant & $12(3)$. & 0 & 0.0 & 0 & 0.0 & 12 & 8.8 & \\
\hline \multicolumn{9}{|c|}{ Family member/guardian uses drug } \\
\hline Yes & $295(73.9)$ & 86 & 68.8 & 100 & 73 & 109 & 79.6 & 0.134 \\
\hline No & $104(26.1)$ & 39 & 31.2 & 37 & 27 & 28 & 20.4 & \\
\hline \multicolumn{9}{|c|}{ Family member been to prison } \\
\hline Yes & $106(26.6)$ & 37 & 29.6 & 49 & 35.8 & 20 & 14.6 & 0.000 \\
\hline No & $293(73.4)$ & 88 & 70.4 & 88 & 64.2 & 117 & 85.4 & \\
\hline
\end{tabular}

\subsection{Family Socio-economic Status}

Table 3 below shows information on the socio-economic status relating to respondents families. The results shows that $60 \%$ of the respondents reported that they are on the streets because of economic challenges (poverty) they experienced at home, and thus hope to find jobs in urban cities. A higher proportion of them were in Bamenda (70.4\%) compared to $(64.2 \%)$ in Douala and $(49.6 \%)$ in Yaoundé. In contrast, in Yaoundé there was a relatively higher proportion of children on the streets due to orphan-hood $(27.7 \%)$ compared to the other two regions $(\mathrm{p}=0.001)$. Overall, $(75.2 \%)$ respondents reported that their parents/guardians never gave them money even for basic necessities. Bamenda with (84\%) had the highest proportion of parents who did not care to give money for necessities followed by Yaoundé with $(73.7 \%)(p=0.017)$.

Only $13.5 \%$ of the respondents accepted that their parents/guardians earned enough money (income) to provide their basic necessities. This was significantly different amongst the cities with Bamenda having the highest proportion of $15.2 \%$ followed by Yaoundé with 13.1 and Douala with $12.41 \%$. $(\mathrm{P}=0.011)$. The majority of street children $(82.7 \%)$ indicated that their parents never used to buy them Christmas or birthday gifts.

Also, (74.7\%) of parents/guardians were not always able to provide sufficient meals for their children. The respondents $(11.8 \%)$, also indicated that they had to stay some days without a meal. The majority of participants in Bamenda $(63.2 \%)$ had to always provide meals for themselves and their siblings while still at home compared to only $9.5 \%$ in Douala and $11.7 \%$ in Yaoundé $(\mathrm{p}=0.000)$.

The results also revealed that $11.3 \%$ of the respondents provided financial support to their family while still at home. Overall, street children were mainly on the streets because they thought that their parents were very poor $(84.5 \%)$. This sentiment was most common in Yaoundé (93.4\%) followed by Douala $(92.7 \%)(p=0.000)$.

Table 3. Family socio-economic status.

\begin{tabular}{|c|c|c|c|c|c|c|c|c|}
\hline \multirow[t]{2}{*}{ Characteristics } & \multirow{2}{*}{$\begin{array}{l}\begin{array}{l}\text { Total } \\
(\mathbf{n}=399)\end{array} \\
\mathbf{N}^{\mathbf{0}} \mathbf{( \% )} \\
\end{array}$} & \multicolumn{2}{|c|}{$\begin{array}{l}\text { Bamenda } \\
(\mathrm{n}=125)\end{array}$} & \multicolumn{2}{|c|}{$\begin{array}{l}\begin{array}{l}\text { Douala } \\
(n=137)\end{array} \\
(n-10\end{array}$} & \multicolumn{2}{|c|}{$\begin{array}{l}\text { Yaoundé } \\
\text { (137) }\end{array}$} & \multirow[t]{2}{*}{$\begin{array}{l}P \text { - } \\
\text { value }\end{array}$} \\
\hline & & $\mathbf{N}^{0}$ & $\%$ & $\mathbf{N}^{\mathbf{o}}$ & $\%$ & $\mathbf{N}^{\mathbf{0}}$ & $\%$ & \\
\hline \multicolumn{9}{|l|}{ Why are you living on the streets? } \\
\hline Orphan-hood & $82(20.6)$ & 19 & 15.2 & 25 & 18.3 & 38 & 27.7 & \multirow{3}{*}{0.011} \\
\hline Earning income for family & $73(18.3)$ & 18 & 14.4 & 24 & 17.5 & 31 & 22.6 & \\
\hline Employment & $244(61.2)$ & 88 & 70.4 & 88 & 64.2 & 68 & 49.6 & \\
\hline Guardians always give money for their necessities & $13(3.3)$ & 5 & 4 & 5 & 3.7 & 3 & 2.2 & 0.017 \\
\hline Guardians earned enough to provide for their needs & $54(13.5)$ & 19 & 15.2 & 17 & 12.4 & 18 & 13.1 & 0.001 \\
\hline Guardians always provided enough meals for respondent and sibling & $20(5)$ & 6 & 4.8 & 8 & 5.8 & 6 & 4.4 & 0.103 \\
\hline Respondent and sibling always stayed for days without a meal & $47(11.8)$ & 13 & 10.4 & 17 & 12.4 & 17 & 12.4 & 0.283 \\
\hline Respondent always had to provide a meal at home & $108(27.1)$ & 79 & 63.2 & 13 & 9.5 & 16 & 11.7 & 0.000 \\
\hline Respondent always had to provide financial support to the family while at home & $45(11.3)$ & 15 & 12 & 15 & 11 & 15 & 10.9 & 0.619 \\
\hline On the streets because they think their parents are very poor? & $337(84.5)$ & 82 & 65.6 & 127 & 92.7 & $\begin{array}{l}12 \\
8\end{array}$ & 93.4 & 0.000 \\
\hline $\begin{array}{l}\text { Parents always give respondent and sibling gifts during Christmas and on their } \\
\text { birthdays? }\end{array}$ & $7(1.8)$ & 7 & 5.6 & 0 & 0 & 0 & 0 & 0.001 \\
\hline
\end{tabular}




\subsection{Dysfunctional Families}

The results in table 4 shows that $(73.2 \%)$ of respondents reported that their parents/guardians used to fight and argue in a loud manner. (74.2\%) of the respondents also reported parents getting drunk. The results also showed that, (54.4\%) of the respondents never used to eat together with their entire family while still at home and this proportion differed by region with Yaoundé (67.9\%) having the highest proportion and Douala $(29.2 \%)$ having the least $(\mathrm{p}=0.00)$.

There was an overall agreement in the results showing that majority of the respondents (78.5) never used to watch movies or television together with their parents or go out pleasurable outing trips with their parents. Some respondents (73\%) never found their houses to be peaceful. The respondents $(79.5 \%)$ indicated that their parents always had problems and were unhappy all the time that made them uncomfortable to stay at home.

Table 4. Dysfunctional families.

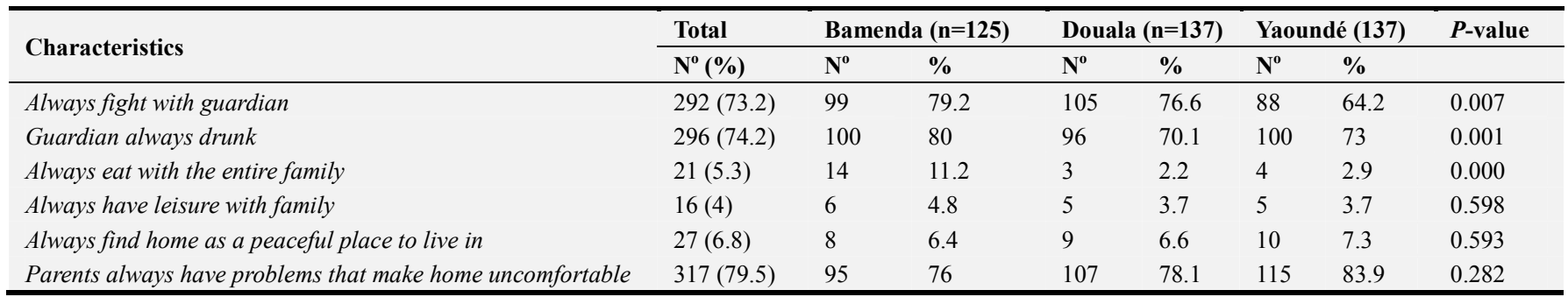

\subsection{Harsh Discipline and Disrespect from Parent(s)/Guardian(s)}

Although the parent(s)/guardians' reactions whenever the respondents committed an offense differed by region $(\mathrm{p}=0.001)$, some similarity was noticed in Yaoundé and Douala because in Yaoundé (80.3\%) of the respondents reported mainly beaten as punishment for any crime committed while Douala reported (79.6\%). Majority of the respondents $(76.7 \%)$ fell sick after receiving beating from their parent(s)/guardian(s) and the proportion of respondents were consistently high across the three regions $(\mathrm{p}=0.408)$.

Most of the parent(s)/guardians never discussed with their kids to find out why they would have committed an offense (77.94\%). There was no significant difference by region $(\mathrm{p}=0.125)$. Almost three quarters of the kids $(74.94 \%)$ did not feel free or at ease with their parent(s)/guardian(s). There were slight differences observed among the regions with $77.6 \%$ in Bamenda, $75.9 \%$ in Douala and $71.5 \%$ in Yaoundé (Table 5).

The respondents $(73.2 \%)$ reported that they stayed away or escaped from home whenever they were punished for an offense. $78.95 \%$ of the respondents escaped to the streets after being punished, and $13 \%$ escaped to meet friends who were already on the streets after being punished. These findings were common across all regions $(\mathrm{p}=0.218)$.

All the respondents from Bamenda indicated that their parent(s)/guardian(s) sometimes or always locked them out of the house when they committed an offense or when they escaped from punishment. In Douala and Yaoundé only 6.6\% of the respondents indicated that they were never locked outside of the house when they committed an offense or when they escaped from punishment. The differences in the regions were statistically significant $(\mathrm{p}=0.034)$ (Table 5).

Table 5. Harsh discipline from parents / guardian(s).

\begin{tabular}{|c|c|c|c|c|c|c|c|c|}
\hline \multirow[t]{2}{*}{ Characteristics } & \multirow{2}{*}{$\begin{array}{l}\text { Total } \\
\mathbf{N}^{\mathbf{0}}(\%)\end{array}$} & \multicolumn{2}{|c|}{$\begin{array}{l}\text { Bamenda } \\
(n=125)\end{array}$} & \multicolumn{2}{|c|}{ Douala $(n=137)$} & \multicolumn{2}{|c|}{ Yaoundé (137) } & \multirow[t]{2}{*}{$P$-value } \\
\hline & & $\mathbf{N}^{\mathbf{0}}$ & $\%$ & $\mathbf{N}^{\mathbf{0}}$ & $\%$ & $\mathbf{N}^{\mathbf{0}}$ & $\%$ & \\
\hline \multicolumn{9}{|l|}{ Reaction of guardian when respondent committed an offense } \\
\hline Beating & $293(73.4)$ & 74 & 59.2 & 109 & 79.6 & 110 & 80.3 & \\
\hline Advice & $44(11)$ & 22 & 17.6 & 10 & 7.30 & 12 & 8.8 & 0.001 \\
\hline Didn't even care & $62(15.5)$ & 29 & 23.2 & 18 & 13.1 & 15 & 11 & \\
\hline Always fall sick after being beaten & $306(76.7)$ & 91 & 72.8 & 111 & 81 & 104 & 75.9 & 0.408 \\
\hline Guardian always wanted to know the reason for the offense & $13(3.3)$ & 6 & 4.8 & 4 & 2.9 & 3 & 2.2 & 0.125 \\
\hline Feels at ease with guardian & $26(6.5)$ & 5 & 4 & 11 & 8 & 10 & 7.3 & 0.535 \\
\hline Always escaped when punished & $292(73.2)$ & 99 & 79.2 & 99 & 72.3 & 94 & 68.6 & 0.218 \\
\hline Always escape to the streets & $315(79)$ & 96 & 76.8 & 111 & 81 & 108 & 78.8 & 0.738 \\
\hline Always locked up at home & $308(77.2)$ & 105 & 84 & 104 & 75.9 & 99 & 72.3 & 0.034 \\
\hline
\end{tabular}

\subsection{Disrespect from Guardian(s)}

The results showing disrespect from parents/guardians revealed that $96.5 \%$ of the respondents have been ridiculed by their parents/guardians. This was most prevalent in Yaoundé where $97.1 \%$ of the respondents had been ridiculed by their parents. The frequency of ridicule differs by region $(\mathrm{p}=0.049)$. Also parents/guardians embarrassed their children 
in public or in front of their children friends $(p=0.229)$. Parents/guardians unfairly compared their kids to someone else, such as their siblings or themselves $(p=0.542) .61 .7 \%$ of the respondents indicated that their parents always compared them to others. Also, the sentiment on parents/guardians ignoring their children ( $p$-value $=0.012$ ), and not respecting their children as people $(\mathrm{p}$-value $=0.000)$ made the children to accept blame for something they think the child might have done.

Table 6. Disrespect from Parents/Guardians.

\begin{tabular}{|c|c|c|c|c|c|c|c|c|}
\hline \multirow{2}{*}{ Characteristics } & \multirow{2}{*}{$\begin{array}{l}\text { Total } \\
\text { No (\%) }\end{array}$} & \multicolumn{2}{|c|}{ Bamenda $(n=125)$} & \multicolumn{2}{|c|}{ Douala $(n=137)$} & \multicolumn{2}{|c|}{ Yaoundé (137) } & \multirow[t]{2}{*}{ P-value } \\
\hline & & No & $\%$ & No & $\%$ & No & $\%$ & \\
\hline Always ridiculed by guardian & $224(56.1)$ & 74 & 59.2 & 75 & 54.7 & 75 & 54.7 & 0.049 \\
\hline Always embraced by guardian in public & $215(53.9)$ & 79 & 63.2 & 70 & 51.1 & 66 & 48.2 & 0.229 \\
\hline Always unfairly compare respondent to others & $246(61.7)$ & 80 & 64 & 77 & 56.2 & 89 & 65 & 0.542 \\
\hline Always ignored by guardian & $254(63.7)$ & 93 & 74.4 & 78 & 56.9 & 83 & 60.6 & 0.012 \\
\hline Not always respected by guardian & $129(32.3)$ & 72 & 57.6 & 27 & 19.7 & 30 & 21.9 & 0.000 \\
\hline Always made respondent accept blame untruthfully & $122(30.6)$ & 79 & 63.2 & 20 & 14.6 & 23 & 16.8 & 0.000 \\
\hline
\end{tabular}

\section{Discussion (Please, Also Number This Section Chronologically)}

In Cameroon just like some other low and middle income countries, children reported various reasons why they had to run away from their homes into the urban streets as being the hope to find comfort, love and a better life $[6,7,10]$. This decision often turn out to be a bad one but when the situation at home (socio-economic status of the family, dysfunctional homes, maltreatment, lack of affection among others), pushes them into desperation, they are left with no other option than to run to the streets with hope of opportunities, community support and love [7, 13, 14].

\subsection{Demographic Profile}

Of the total participants, $80.2 \%$ were male and $19.8 \%$ female. $83 \%$ of the participants were Christians. $80 \%$ of the participants had no contact with their family members. More than half of the participants begged to make ends meet while a good number of them were engaged in other activities like selling in bars, shining shoes, washing cars and worst of all engaging into mini theft as shown in (table 1).

\subsection{Family Profile/Family Socio-economic Status}

The majority of street children have parents who are less educated, abused substances, while others come from polygamous families (In the current study, slightly more than half of the respondents $50.9 \%$ came from polygamous homes), with parents having only manageable sources of income leading to poor economic status and making it difficult for their parents to provide them with basic needs $[13,14]$.

The Republic of Cameroon has experienced its own share of economic crisis and continues to face the challenge of many families living in poverty. Unemployment is high even among the highly educated population thus making it very difficult for parents with little education and no skills to easily find a job, capable to take care of their family [3-5, $15]$.

Some polygamous families experience the situation of economic (poverty) differently. However not every child from a polygamous family eventually becomes a street child, but for those who are unable to get protection, support and love from their parents $[4,5,15]$. Children from such families as mentioned above always have difficulties to feed as some days may go by without them having any food in the house for them and their siblings thereby pushing some of them to embark on the option of running into the streets to look for opportunities to make money to support their families. This also helps to explain why some of the respondents began involving into street life while still at home since they were looking for things/jobs to do on the street to make money to be able to financially support their families just as similar patterns among street children have been reported in other studies as they concur with this results $[4,6,7,9,13,14]$.

\subsection{Dysfunctional Families}

Dysfunctional families could be seen as another strong factor affecting children in their family homes that lead to the creation of street life ideas in children [15]. The respondents (73.2\%) reported frequent fighting among their parents while they were still at home. Most parents/guardians get drunk and start fighting with the children and their mothers thus making the home a very uncomfortable place to live in and this intend pushes the children to the streets where they hope to find affection and care which they lack [15].

\subsection{Harsh Discipline}

Harsh discipline and disrespect of children can also be found from the results reported by the street children as reasons for them to run away from home. Other studies also reported parents using beating as the correcting measure when a child commits an offence $[3,4,15]$. In this current study, $(73.4 \%)$ of the respondents reported being beaten each time they committed an offence. Only $(11 \%)$ of the total 
participants did mention advice from parents when they committed an offence while they were still at home. Participants also reported being sick after receiving beatings as punishment for even the very little offenses, thus running away from home to the street was an option because (79\%) of the participants mentioned running to the street after being beaten.

Also another reason for children to run to the streets from the results could be seen from parents influence. Some parents attitude of locking their children out of home when they commit a crime only helps to introduce the child to new friends on the streets and this act makes it easier for the same child to finally make a decision to leave home finally and to the streets as he already have friends whom have been keeping him company in the past $[3,4]$. In this study, $77.2 \%$ of respondents reported being locked out side at night by their parents/guardians for committing a crime.

\subsection{Disrespect from Parents}

Every child need respect, protection and love from their families and parents. When these are absent the child feels lonely and depress with no one to turn to $[3,5,15]$. From the study results, some of the respondents reported of always being ridiculed by their parents/guardians, embarrassed and unfairly treated and above all making them to accept blames untruthfully for crimes they did not commit. All the above could be seen as reasons that might have contributed to pushing the children to run away from homes to the streets in Cameroon.

\subsection{Coping}

These children find it very difficult coping at home when parents cannot afford their basic needs and provide them with the love they need thus only $(1.8 \%)$ of the respondents in this study could testify receiving gifts during Christmas. Street children in Cameroon and those in other low and middle income countries do witness similar results when it comes to coping measures on the street even though some children in other African countries might cope better than others depending on their community, culture and kind of intervention they receive from their government, Religious and other non-governmental organisations $[4,9,13]$.

\subsection{Strength/Weaknesses}

This study has much strength. To begin with, 79 girls were recruited to participate for this study and is the only quantitative study on street children which has succeeded to recruit this many girls to participate. Secondly, because of the large data which included only minors more consideration had to be given that is, recruiting up to six trained experienced research assistance to help in the administering of the questionnaire. Finally this data is current and will help to make available the present situation of street children in Cameroon as the last published data on street children in Cameroon date as far back as 2001 which is about 15 years ago.
The study also experienced some weakness and the main one of them is that it relied solely on self reported data which was not possible to verify. For example the children's ages, family background among others could not be verified before analysis. Also the study could not collect data from all the 10 regions in Cameroon because of insufficient finance thus only 3 of the regions were selected.

\section{Conclusion}

This study concludes that the respondents experienced unfavourable home circumstances which contributed to them leaving home to dwell on the streets. Poverty, hunger and troublesome parents were among the reported circumstances that forced the participants to become street dwellers. Government should play a major role in assisting these children to ensure that their rights are not violated and that their basic needs are met.

\section{Acknowledgements}

Thanks goes to the Discipline of Public Health Medicine, Department of Nursing \& Public Health, College of Health Sciences, University of Kwazulu-Natal Durban, South Africa for providing all necessary support towards the completion of this work. Also, thanks goes to Mr. Ndenkeh Nforbewing Jackson Jr. for his contribution towards data analysis.

\section{References}

[1] WHO/UNAIDS. (2015). Global standards for quality health care services for adolescents: a guide to implement a standards driven approach to improve the quality of health care services for adolescents. Geneva: World Health Organization.

[2] UNICEF. (2012). The state of the world's children 2012: Excluded and invisible: United Nations Publications Report No: 9280639161.

[3] Matchinda B., (1999). The impact of home background on the decision of children to run away: the case of Yaoundé City street children in Cameroon. Child Abuse \& Neglect Journal; 23 (3): 245-55.

[4] Nasir, M., (2013). A study to investigate the family background of street children at Lahore. International Journal of Physical and Social Sciences, 3 (4), p. 194.

[5] Tchombe, T. M. S., Shumba, A., Lo-Oh, J. L., Gakuba, T. O., Zinkeng, M. and Teku, T. T., (2012). Psychological undertones of family poverty in rural communities in Cameroon: resilience and coping strategies. South african journal of psychology, 42 (2), pp. 232-242.

[6] Ezeokana, J. O., Obi-Nwosu, H. and Okoye, C. A., (2014). Influence of Street Life and Gender on Aggression and Selfesteem in a Sample of Nigerian Children. International Review of Management and Business Resilience-Enablers among Street Children. J Soc Sci, 39 (3), pp. 265-274.

[7] Abourahme, Nasser. (2013). "'The street'and 'the slum': Political form and urban life in Egypt's revolt." City 17, no. 6: 716-728. 2013. 
[8] Tchombe, Therese M, Nuwanyakpa, Mopoi Etmonia, Tarpeh., (2001). Street children in Cameroon: Problem and Perspectives. Journal of African Psychology in Africa; South of the Sahara, the Caribbean, and Afro-Latin America, Volume 11 (2), Pp 101-12 5

[9] Uddin, M. J., Sarma, H., Wahed, T., Ali, M. W., Koehlmoos, T. P., Nahar, Q., \& Azim, T., (2014). Vulnerability of Bangladeshi street-children to HIV/AIDS: a qualitative study. BMC Public Health, 14, 1151. http://doi.org/10.1186/14712458-14-1151.

[10] Strobbe, F., Olivetti, C. and Jacobson, M., (2013). Breaking the net: family structure and street-connected children in Zambia. The Journal of Development Studies, 49 (5), pp. 670688 .

[11] Oppong Asante, K., Meyer-Weitz, A., \& Petersen, I., (2014). Substance use and risky sexual behaviours among street connected children and youth in Accra, Ghana. Substance
Abuse Treatment, Prevention, and Policy, 9, 45. http://doi.org/10.1186/1747-597X-9-45.

[12] Vernig, P. M., (2011). Family roles in homes with alcoholdependent parents: An evidence-based review. Substance use \& misuse, 46 (4), pp. 535-542.

[13] Myburgh, C., Moolla, A. and Poggenpoel, M., (2015). The lived experiences of children living on the streets of Hillbrow. curationis, 38 (1), pp. 1-8

[14] Aransiola, J. O., (2013). Providing Sustainable Supports for Street Children in Nigeria: Stakeholders Challenges and the Policy Options Available. Advances in Applied Sociology, 3 (03), p. 172.

[15] Lukman, Z. M., Nasir, R., Fauziah, I., Sarnon, N., Chong, S. T., Kamal, M. M. and Rusyda, H. M., (2011). The relationship between dysfunctional family and the involvement of children in prostitution. world applied sciences journal, 12, pp. 7-12. 